\title{
Bitemarks and Evidence in Forensic Odontology
}

\author{
Orfeas K Peridis* \\ Free Lancer Medical Examiner, PhD University of Athens Medical School, Greece
}

Submission: April 13, 2017; Published: May 24, 2017

*Corresponding author: Orfeas K Peridis, Free Lancer Medical Examiner, doctor of public health, sociologist Athens, PhD University of Athens Medical School, 1rst Egeou str, 14671 Nea Erythrea Attica, Greece, Tel: 0030 6970157277; Email: orfeas.peridis2015@gmail.com

\begin{abstract}
The identification of a person is important in criminology, and forensic odontologists, are key persons in recognition of the denture wherein due to the imprint of a bite, and hence the conviction or acquittal of an individual suspect. The footprint of a bite can be studied on the skin, the wax from a photograph indirectly, or a scanned imprint teething model in food or elsewhere. This paper shows that bitemarks constituted reliable data to identify an individual, and that the measurements obtained from wax, photographs or scanned images diverge only $1 \mathrm{~mm}$. The aim of this work is, as mentioned briefly some information on the content of Forensic Medicine of the Mouth, to show how the findings from the oral examination serve to identify the corpse by fire.
\end{abstract}

Keywords: Forensic stomatology; Odontogramma; Carcass identification; Forensic odontology; Dental record; Body identification

\section{Introduction}

The identification of a person is an important point in forensic studies as fingerprints and DNA method is very widely used techniques for this purpose. However stomatology data and prostheses can also be very useful. During 1453 AD attempted first recognition corpse teeth. He was the corpse of John Talbot 80 years old warrior killed in battle of Castillon (Swanson 1967).

In the late 19th century it is presented by Professor of Dentistry in Paris Oscar Amoldo. The first announcement was made in Moscow on dentist judicial interest and was entitled: The role of the dentists in the identification of the victims of the catastrophe of the "Bazar de la charite". In 1898 he wrote the first book dentist judicial entitled: L 'art Dentaire en Medecine Legale, putative rightly so that the real father of Forensic this industry.

Research and practice of forensic dentistry has gained ground since the 2 nd World War that one of their first significant applications was the recognition of Hitler from his teeth. It is now widely accepted that $\mathrm{n}$ alignment, configuration, the angulation, the occlusion and tooth fillings are both features that make denture so unique as the person it belongs to be identified with precision and clarity of his teeth. In addition to cases of murder and rape, criminals often leave behind imprints of the teeth (the victim in foods eg apple, cheese, chocolate or chewing gum). These fingerprints have unique features that allow their comparison with the characteristics of the offender's teeth.
O Sperber acknowledged a murderer from the gum and saliva found on her, which was the only remaining item left behind, it has also been reported that the imprint of teeth even clothes can be reliable evidence. One culprit was identified among 114 other suspects by comparing teeth with a dental cast of the dental impression. An unidentified body was identified by 0 Peridis [1] based dental elements and templates. In another case, a murderer confessed his crime because of data arising against the imprints of the bite marks, dental models and photography. Recent computer programs are used to help establish dental identification factor elements considered sophisticated and reliable.

\section{Display Case $1 \& 2$}

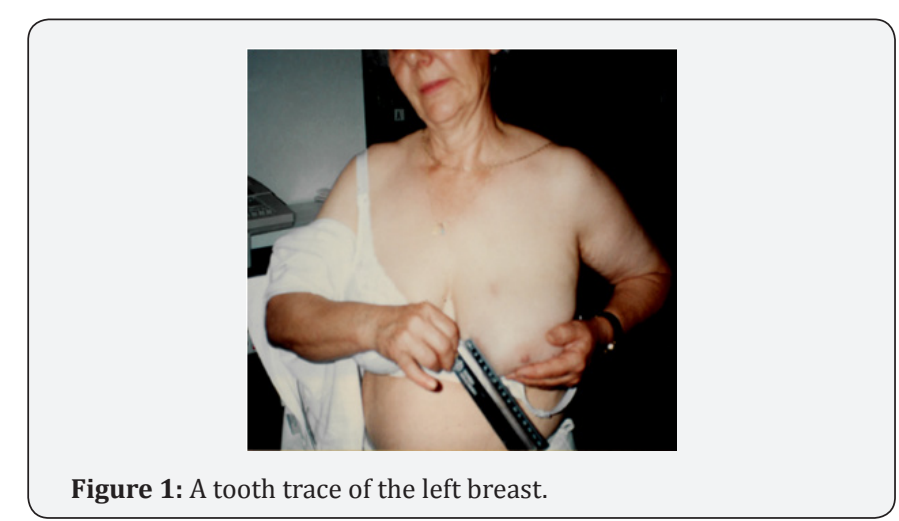


This is an old woman who wanted to have younger lover (1997, Peloponnese) but in the end it turned out that he wanted to rob and denounced him to the police. The 'perpetrator' lover leave a tooth trace of the left breast and particularly the area 11 with the upper jaw crescent shape cut (Figure 1). Since control of my examination in 'suspect' detained offender lover indeed I noticed that the left area 11 maxilla was crescentic form bevelled and documentation guilty (Figure 2).
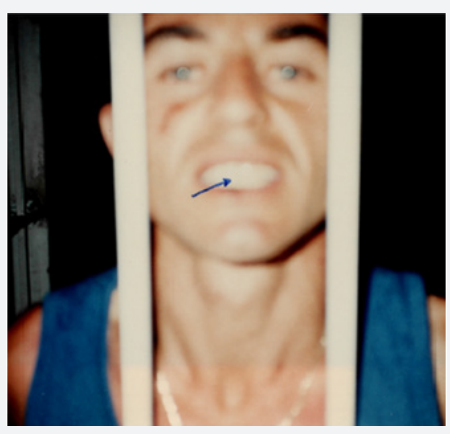

Figure 2: The left area 11 maxilla was crescentic form.

This man dentist who died (1998, Peloponnese) and burned alive in a car accident. The mandate of the Traffic Police, was the first conducted autopsy for the exact cause of death and also confirmed by the identification of the coroner Dr. Orfeas Peridis [2] that the body found unknown belongs to Ch. Sp... 70 years old, resident of Molai, Laconia, following total carbonization of road accident.

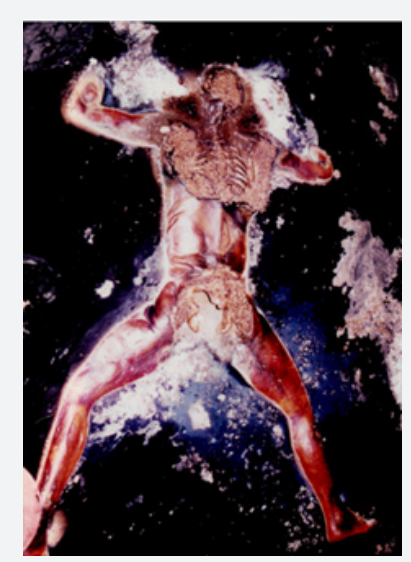

Figure 3: Macroscopic finding of soot in the trachea.

Consideration of autopsy by conducting as a Coroner found out that his death first became alive (due to the macroscopic finding of soot in the trachea) (Figure 3) and the other part with the findings of the examination of the mouth of the carcass comparing the data they gave me (the dentist file) and became identified with the activity carried odontogrammatos dentures from 1985 to the upper jaw forward and was placed metal acrylic bridge $[3,4]$. It goes without saying that the results of this examination was based and scientifically documented identification of the corpse.

\section{Discussion}

The imprint of a bite in the body of a victim or to elements of the surroundings (trace, imprint, chewing gum, foods) can be significantly and evidence that the perpetrator leaves unwittingly behind. Certainly, the collection of such data and their valuation is a complex process but as a first essential step is to immediately record the bite because the morphology and individual dimensions can be changed quickly $[5,6]$. Additionally should be taken photos without distortion which both they and the images from the computer to include a scale for calculating the real dimensions.

\section{Summary and Conclusion}

With the introduction of an unknown corpse incident whose identification was based on findings from the activity carried odontogramma dentures, view documenting that:

A. Material from the dental record, albeit incomplete, can serve, among other things, and for identifying unknown corpse. With biostatistics research has found that the probability of two people have exactly the same findings of their odontogramma is one in two billion.

B. The data generated by the imprint of a bite on the skin, in wax casts, photos, or scanned images via computer can be regarded as reliable evidence for the identification of a person, as unique as fingerprints.

C. Programs for computers are developed for this purpose, which in use of a scanner and an image may convert the three-dimensional model of the fingerprint in a two-dimensional model that can be measured and compared.

In conclusion it could be pointed out:

A. In cases incineration or amputations or long decomposition of a corpse, the most common way of identification are the findings from odontogramma, and

B. In all organized societies dentists are required by law to have a complete record of their patients (with drawings, radiographs, casts, etc.) not only to perform their functions at the highest level, and to facilitate, with their file Forensic investigations. 


\section{Your next submission with Juniper Publishers will reach you the below assets}

- Quality Editorial service

- Swift Peer Review

- Reprints availability

- E-prints Service

- Manuscript Podcast for convenient understanding

- Global attainment for your research

- Manuscript accessibility in different formats

( Pdf, E-pub, Full Text, Audio)

- Unceasing customer service

Track the below URL for one-step submission https://juniperpublishers.com/online-submission.php 